\title{
The Viability and Utility of Ecclesiastical Demands for HIV and Genotype Medical Tests Information before Church Mediated Marital Union in Nigeria
}

\author{
Allen Nnanwuba Adum \\ Department of Mass Communication, \\ Nnamdi Azikiwe University, Awka, \\ Anambra State, Nigeria \\ Ogochukwu Ekwenchi \\ Department of Mass Communication, \\ Nnamdi Azikiwe University, Awka, \\ Anambra State, Nigeria \\ Emeka Odogwu \\ Department of Mass Communication, \\ Nnamdi Azikiwe University, Awka, \\ Anambra State, Nigeria \\ Kobimdi Umeh \\ Department of Mass Communication, \\ Nnamdi Azikiwe University, Awka, \\ Anambra State, Nigeria
}

\begin{abstract}
Sickle cell disease is the commonest genetic disease in Nigeria; among Africans and the generality of the black race. Sickle cell disease (SCD) is a group of blood disorder typically inherited from a person's parents. It results in an abnormality in the oxygen-carrying protein hemoglobin in the red blood cells. The issue of genotype incompatibility among prospective couples, and decisions on marriage in the face of this health condition, can have significant implication on the control of this disease in Nigeria and any other country. HIV epidemic in Nigeria has recorded high numbers in persons living with HIV and deaths related to AIDS. Reports from UNAIDS show that an estimated 1.9 million persons are living with HIV in Nigeria; $1.4 \%$ of adults between ages $15-49$ live with the virus. This statistics suggest that a lot of work is still needed to scale up HIV treatment and prevention services. The church, through religious doctrines and propagation of religious teachings, has a stronghold on the perception and acceptance of lifestyles in our multi-cultural African society. As such, our discourse examines health implications of marriage, with a focus on the viability and utility of premarital medical tests for sickle cell disease and HIV, as a prerequisite for matrimony in the church in Nigeria.

Key words: Sickle cell, genotype medical test information, church mediated marital union, ecclesiastical demands

DOI: $10.7176 / \mathrm{DCS} / 9-6-12$

Publication date:June $30^{\text {th }} 2019$

\section{INTRODUCTION}

Marriage is a socially or ritually recognized union between spouses that establishes rights and obligations between the spouse and any resulting biological or adopted children and affinity. In Nigeria, it is recognized by the state, religious institutions, traditional institutions and social groups. When marriage is performed by government institution (court) in accordance with marriage laws of the jurisdiction, without religious content, it is known as civil marriage; when it is performed within religious content under the auspices of a religious institution, it is referred to as sacramental marriage in Catholicism and nikah in Islam. In Igbo ethic group it is
\end{abstract}


referred to as Igbankwu. Various names are given to matrimony in other traditions and faith, with constraints as to what constitutes and qualifies interested persons for this union. Marriage, like other social relationships exerts considerable influence on health, either on parents or children.

Sickle cell disease (SCD) is a group of blood disorder typically inherited from a person's parents. It results in an abnormality in the oxygen-carrying protein hemoglobin in the red blood cells. Medical researches on this disease show sickle cell problem usually begin around the ages of 5 to 6 months. Some of the health indicators of sickle cell disease are anemia, attacks of pain (also known as sickle cell crisis), swelling of the hands and feet, bacterial infections and stroke. People suffering from this disease have an average life expectancy of 40 to 60 years. Booth, Inusa and Obaro (2010), define Sickle Cell Disease (SCD) as a collective term for several genetic disorders in which the carrier's hemoglobin is structurally abnormal, resulting in the episodic formation of sickle shaped red blood cell and a range of clinical manifestations.

Nigeria records about 150,000 sickle cell births annually, but $75 \%$ of this number do not see their fifth birthday; also, over 40 million Nigerians are healthy carriers of the sickle cell gene, while over 150,000 are born each year with the sickle cell anemia. About 4.4 million people have sickle cell disease, while an additional 43 million have sickle cell trait. Sickle cell anemia, reportedly, killed about 114,800 persons in 2015 (National Sickle Cell Centre Reprot, 2019).

HIV epidemic in Nigeria has also recorded high numbers in persons living with HIV and deaths related to HIV/AIDS. According reports from unaids.org, an estimate of 1.9 million persons are living with HIV in Nigeria; $1.4 \%$ of adults between ages $15-49$ live with the virus. Although this number is a decline from what was recorded in the past decade, a lot of work is still needed to scale up HIV treatment and prevention services.

Human Immunodeficiency Viruses (HIV) are two species of Lentivirus (a subgroup of retrovirus) that causes HIV infection and over time acquired immunodeficiency syndrome (AIDS). AIDS is a condition in humans in which progressive failure of the immune system allows life-threatening opportunistic infections and cancers to thrive. Without treatment, average survival time after infection with HIV is estimated to be 9 to 11 years, depending on the HIV subtype. In most cases, HIV is a sexually transmitted infection and occurs by contact with or transfer of blood, pre-ejaculate, semen, and vaginal fluids. Research has shown (for both same-sex and opposite-sex couples) that HIV is untransmissable through condomless sexual intercourse if the HIV-positive partner has a consistently undetectable viral load. Non-sexual transmission can occur from an infected mother to her infant during pregnancy, during childbirth by exposure to her blood or vaginal fluid, and through breast milk. Within these bodily fluids, HIV is present as both free virus particles and virus within infected immune cells.

The church through religious doctrines and propagation of religious teachings has a stronghold on the perception and acceptance of lifestyles in our multi-cultural African society. Although spiritual development is continually interpreted in many ways, one of its common and socially accepted interpretation is that it includes those aspects of personal development that help people understand who they are and what life is about and this arguably includes living healthy (with an exception to religious fasting). Religious institutions spend most of their time engaging host communities, thereby shaping social norms, attitudes, beliefs and realities. Religion and more specifically faith-based organizations can have an effect on socio-cultural factors that increase or decrease risk of infection; and offer preventive interventions to the wider community (Ochillo, Teijlingen \& Hind, 2017).

SCD and HIV are evidently a cause to worry, given the statistics shown above, hence the need for ecclesiastical demands for medical test for these two ailments before marriage. Religious institutions have become necessary partners in preventive activities on public health issues.

\subsection{SCD Prevalence in Nigeria}

Nigeria has high rates of both SCD and HIV, which is attributed to poor awareness and knowledge of preventive measures of these diseases and treatment when necessary, especially among those in the reproductive age in the country. Groose, Odame, Atrash, Amendah, Piel \& Williams (2011), posit that mortality among African children has increased as a result of SCD among children who are 5 years and younger. The number of persons affected with SCD has been increasing despite government efforts to address the issue. This high level of SCD is attributed mainly to a low level of awareness about SCD, as well as inadequate centresfor counseling in the country (Durotoye, Salaudeen, Babatunde \& Bosah, 2013). The disease is widespread even among the urban residents and elite communities that have access to effective health care.

There is a low level of knowledge about SCD among many Nigerians. There is misinformation, myths, inaccurate diagnosis, and stigmatization about SCD in Nigeria (Adeyemo, Omidiji \& Shabi, 2007). According to Afolayan and Jolayemi (2011), Nigeria has a population of approximately 150 million with a yearly growth rate of about 3.2\%. However, the number of individuals affected by SCD is not known because the majority of them 
are born in rural areas and do not survive past childhood. It is, however, estimated that $2.3 \%$ of the Nigerian population suffers from SCD, and $25 \%$ of them are carriers of the abnormal hemoglobin gene (Afolayan $\&$ Jolayemi, 2011).

Anie, Egunjobi, and Akinyanju (2010) stressed that SCD is a worldwidechallenge with psychosocial implications. Anie et al. pointed out that Nigeria has thehighest population of individuals with SCD with an estimated 150,000 births per year. InNigeria, beliefs are normally determined by religious, as well as cultural values thatimpact health behaviors.

According to Adewoyin (2015), SCD in Nigeria forms a small part of clinical practice of general medical practitioners. Adewoyin (2015) also stressed that there is a lack of devoted sickle cell centres. Modell and Darlison (2008) indicated that approximately 5\% to $7 \%$ of the world population have abnormal hemoglobin gene. A majority of the SCD cases are reported in sub-Saharan Africa, especially Nigeria (Modell \&Darlison, 2008). Prevalence of sickle cell trait ranges from $10 \%$ to $45 \%$ in varying parts of sub-Saharan Africa. In Nigeria, the carrier prevalence is approximately $20 \%$ to $30 \%$ of the population. Moreover, the disease affects approximately $2 \%$ and $3 \%$ of the total population of Nigeria of about 160 million (Adewoyin, 2015).

\section{IMPORTANCE OF GENETIC TESTING FOR SICKLE CELL DISEASE IN NIGERIA}

Premarital screening for the diagnosis of SCD is crucial towards reducing the condition among newborns (Omuemu, Obarisiagbon, \&Ogboghodo, 2013). Premarital screening allows for an individual's health-related reproductive risk to be determined. Oyedele, Emmanuel, Gaji, and Ahure (2015) stated that premarital genetic screening offers a chance for people to become aware of their genetic predisposition to disease. The test helps couples to understand the possible genetic composition of their children. Therefore, premarital testing is one of the most reliable methods of preventing genetic diseases, such as SCD. Screening facilitates the identification of carriers and at-risk marriages. According to Fernandes, Januario, Cangussu, Macedo, and Viana (2010), neonatal screening programmes can also be used to assess the possibility of deaths among children affected by SCD. The type of genotype is likely to facilitate the identification of SCD, as well as its complications. Patients' family members can be enlightened so as to minimize SDC-related mortality.

Premarital screening programmes have been shown to be successful in reducing cases of hemoglobinopathies in countries such as Turkey and Saud Arabia (Okyay, Çelenk, Nazlıcan \& Akbaba). Also, Okyay et al. (2016) highlighted the importance of creating awareness and knowledge about the disorders to encourage would-be spouses to attend genetic counseling clinics before considering marriage.

\subsection{Symptoms of Sickle Cell Disease}

The sickle cell disease has underlying symptoms. These are:

- Sickle cell crisis: The terms "sickle cell crisis" or "sickling crisis" may be used to describe several independent acute conditions occurring in patients with SCD. SCD results in anemia and crises that could be of many types including the vaso-occlusive crisis, aplastic crisis, sequestration crisis, hemolytic crisis, and others. Most episodes of sickle cell crises last between five and seven days. Although infection, dehydration, and acidosis can act as triggers, in most instances, no predisposing cause is identified.

- Vaso-occlusive crisis: The vaso-occlusive crisis is caused by sickle-shaped red blood cells that obstruct capillaries and restrict blood flow to an organ resulting in ischaemia, pain, necrosis, and often organ damage. The frequency, severity, and duration of these crises vary considerably. Painful crises are treated with hydration, analgesics, and blood transfusion; pain management requires opioid administration at regular intervals until the crisis has settled. For milder crises, subgroups of patients manage on nonsteroidal anti-inflammatory drugs (NSAIDs) such as diclofenac or naproxen. For more severe crises, most patients require in-patient management for intravenous opioids; patient-controlled analgesia devices are commonly used in this setting. Vaso-occlusive crisis involving organs such as the penisor lungs are considered an emergency and treated with red-blood cell transfusions. Incentive spirometry, a technique to encourage deep breathing to minimise the development of atelectasis, is recommended.

- Splenic sequestration crisis: Because of its narrow vessels and function in clearing defective red blood cells, the spleen is frequently affected. It is usually infarcted before the end of childhood in individuals suffering from sickle cell anemia. This spleen damage increases the risk of infection from encapsulated organisms; preventive antibiotics and vaccinations are recommended for those lacking proper spleen function. Splenic sequestration crises are acute, painful enlargements of the spleen, caused by 
intrasplenic trapping of red cells and resulting in a precipitous fall in haemoglobin levels with the potential for hypovolemic shock. Sequestration crises are considered an emergency. If not treated, patients may die within 1-2 hours due to circulatory failure.

- Acute chest syndrome: Acute chest syndrome (ACS) is defined by at least two of the following signs or symptoms: chest pain, fever, pulmonary infiltrate or focal abnormality, respiratory symptoms, or hypoxemia. It is the second-most common complication and it accounts for about $25 \%$ of deaths in patients with SCD.

- Aplastic crisis: Aplastic crises are acute worsening of the patient's baseline anemia, producing pale appearance, fast heart rate, and fatigue. This crisis is normally triggered by parvovirus B19, which directly affects production of red blood cells by invading the red cell precursors and multiplying in and destroying them. Parvovirus infection almost completely prevents red blood cell production for two to three days. In normal individuals, this is of little consequence, but the shortened red cell life of SCD patients result in an abrupt, life-threatening situation. Reticulocyte counts drop dramatically during the disease (causing reticulocytopenia), and the rapid turnover of red cells leads to the drop in haemoglobin. This crisis takes 4 days to one week to disappear. Most patients can be managed supportively; some need blood transfusion.

- Haemolytic crisis: Haemolytic crises are acute accelerated drops in haemoglobin level. The red blood cells break down at a faster rate. This is particularly common in patients with coexistent G6PD deficiency.

\section{RELIGION AND HEALTH PROMOTION}

According to Rumun (2014), religion is communal and is defined by boundaries.Religion tends to influence health behaviors. Religion has the potential of promoting a healthy lifestyle. Nevertheless, Levin (2014) argue that faith-based organizations, as well as institutions, have been under used in the promotion of health and disease prevention. Religion has been found to influence health indirectly in various ways, and in Nigeria, some people believe that some diseases are caused by a lack of faith (Rumun,2014). It is only the religious leaders who can encourage premarital genotype testing.Religious institutions have also been involved in the delivery of human services, such as health care. A majority of the earliest health institutions were established by religious communities. Mainly, they focused on health promotion within the underserved societies. Levin (2014) further suggests that faith-based institutions contribute towards health promotion as well as disease prevention. Religious participation has been associated with a decreased rate of morbidity and mortality. Levin recommended the establishment of health-based partnership in the health sector as means of promoting health.

Campbell, Hudson, Resnicow, Blakeney, Paxton \& Baskin (2007), indicate that church-founded health promotion intervention can reach broad populations and can minimize health issues and disparities.Campbell et al. (2007) further stress that church, as well as other religious institutions, may determine members' behavior. Anshel and Smith (2014) argue that religious communities are not immune to various societal conditions. Subsequently, altering the health behavior of the community requires input from individuals who possess credibility and knowledge, as well as a receptive audience. Nonetheless, one group of people (i.e., religious leaders) who are positioned to boost societal change tends to be ignored.

Religious leaders can influence the promotion of health behaviors due to their power of persuasion, weekly captivated audience, exposure to healthy living, and the capability to lead health-related actions. Religious leaders can improve healthy living among their followers (Anshel\& Smith, 2014).

Ruijs, Hautvast, Kerrar, Van der Velden, and Hulscher (2013) argue that the engagement of religious leaders in a health-related intervention is associated with enhanced participation of followers in health interventions. Consequently, the involvement of religious leaders has been linked to progressive health outcomes. Health organizations are, therefore, encouraged to work in partnership with religious leaders aswell as religious groups. The authority of religious leaders might convince the congregation to accept or reject health interventions. For example, religious leaders can be engaged by health organizations, such as UNICEF, to accept vaccination.

Rivera-Hernandez (2015) indicate that clergy within Mexico address healthcare related needs of their followers. Rivera-Hernandez (2015) further states that clergy can offer guidance as well as advice concerning health-related challenges. Religious leaders have a positive influence on the wellness and health of their followers. Rakotoniana, Jean de Dieu, and Barennes (2014) examined the role played by churches in combating HIV/AIDS epidemic. They emphasized that churches occupy a critical, cultural and social position.

According to Lewis (2008), religious institutions contribute to the overall health of the community, primarily because of religious leaders' positive impact on the manners of the society. Gill and Carlough (2008) pointed out 
that the partnerships between the public health sector and faith-based institutions are a strategy for addressing child mortality. For the past decades, faith-based institutions have played a role in the global attempt to improve the welfare and health among the disadvantaged populations. The scope of faith-based activities in the health service has expanded over the past years.

There have also been calls for religious-based institutions to enhance health services through filling the gaps within the health sector (Gill \& Carlough, 2008). Widmer, Betran, Merialdi, Requejo, \& Karpf, (2011) reveal that encouraging partnerships between faith-based institutions and healthservices is an effective means of addressing issues of child mortality in Africa.

\section{CONCLUSION}

Our discourse shows that the place of the religious institution cannot be overemphasized when it comes to the fight against health conditions of epidemic dimensions. Genetic and HIV counseling and medical test information can go a long way in helping individuals to sort out their statuses and serve as some sort of mitigation against the prevalence of epidemic diseases at the very core of society which is the family unit. In this sense, we can conclude that premarital medical tests information, as a prerequisite for marital union, which is obtainable in some Nigerian churches, is not only viable but also useful for the well being of marriage unions.

\section{REFERENCE}

Adewoyin, A. S. (2015). Management of sickle cell disease: A review for physician education in Nigeria (subSaharan Africa). Anemia, 2015, 1-21. https://doi.org/10.1155/2015/791498

Adeyemo, O. A., Omidiji, O. O., \&Shabi, O. A. (2007). Level of awareness of genetic counseling in Lagos, Nigeria: Its advocacy on the inheritance of sickle cell disease. African Journal ofBiotechnology, 6(24), 27582765. https://doi.org/10.5897/ajb2007.000-2441

Afolayan, J. A., \&Jolayemi, F. T. (2011). Parental attitude to children with sickle cell disease in selected health facilities in Irepodun Local Government, Kwara State, Nigeria. Studies on Ethno-Medicine, 5(1), 33-40. https://doi.org/10.1080/09735070.2011.11886389

Anie, K. A., Egunjobi F. E., \&Akinyanju, O. O. (2010). Psychosocial impact of sickle cell disorder: Perspectives from a Nigerian setting. Globalization and Health, 62, 1-15. $\quad$ https://doi.org/10.1186/17448603-6-2

Anshel, M. H., \& Smith, M. (2014). The role of religious leaders in promoting healthy habits in religious institutions. Journal of Religion and Health, 53(4), 1, 046-1, 059. https://doi.org/10.1007/s10943-0139702-5

Booth, C., Inusa B., Obaro, S.K. (2010). Infection in sickle cell disease. Retrieved fromhttp://www.ncbi.nlm.nih.gov

Campbell, M. K., Hudson, M. A. Resnicow, K., Blakeney, N., Paxton, A., \& Baskin, M. (2007). Church-based health promotion interventions: evidence and lessons learned. Retrieved from http://www.ncbi.nlm.nih.gov/pubmed/17155879

Durotoye, I. A., Salaudeen, A. G., Babatunde, A. S., \&Bosah, E. C. (2013). Knowledge and perception of sickle cell disease among senior secondary school students in Ilorin Metropolis. The Tropical Journal of Health Sciences, 20(2), 1-7. Retrieved from https://www.ajol.info/index.php/tjhc

Fernandes, A. P. P. C., Januário, J. N., Cangussu, C. B.,Macedoa, D. L. D., \&Viana, M. B. (2010). Mortality of children with sickle cell disease: A population study. Jornal de pediatria, $\quad 86(4), 279-284$. Retrieved from https://www.journals.elsevier.com/jornal-de-pediatria/

Gill, Z., \& Carlough, M. (2008). Do mission hospitals have a role in achieving Millennium development Goal 5? International Journal of Gynecology\& Obstetrics, 102(2), 198202.https://doi.org/10.1016/j.ijgo.2008.04.003

Grosse, S. D., Odame, I., Atrash, H. K., Amendah, D. D.,Piel, F. B., \& Williams, T. N. (2011). Sickle cell disease in Africa: A neglected cause of early childhood mortality. American Journal of Preventive Medicine, 41(6), S398-S405. Retrieved from http:/www.ajpmonline.org/

Levin, J. (2014). Faith-based initiatives in health promotion: History, challenges, and current partnerships. American Journal of Health Promotion, 28(3), 139-141. https://doi.org/10.4278/ajhp.130403-cit-149 
Lewis, A. (2008). Some positive benefits churches bring to communities. The Ethics and ReligiousLiberties Commission. Retrieved on April 21, 2016, from https://erlc.com/article/some positive-benefits-churchesbring-to-communities

Modell, B., \&Darlison, M. (2008). Global epidemiology of haemoglobin disorders and derived service indicators. Bulletin of the World Health Organization, 86(6), 480- 487. https://doi.org/10.2471/blt.06.036673

Ochillo, M.A., Teijlingen, E.V., Hind, M. (2017). Influence of faith-based organization on HIV prevention strategies in Africa: a systematic review. Retrieved from: http://www.ncbi.nlm.nih.gov

Okyay, R. A., Çelenk, Ö.,Nazlıcan, E., \&Akbaba, M. (2016). Haemoglobinopathyawareness among young students in Turkey: Outcomes of a city-wide survey. Plos ONE, 11(7), 1-8.doi:10.1371/journal.pone.0159816

Omuemu, V. O., Obarisiagbon, O. E., \&Ogboghodo, E. O. (2013). Awareness and acceptability of premarital screening of sickle cell disease among undergraduate students of the University of Benin, Benin City, Edo State. Journal of Medicine and Biomedical Research, 12(1), 91-104. https://doi.org/10.4314/nmp.v58i3.63125

Oyedele, E. A., Emmanuel, A., Gaji, L. D., \&Ahure, D. O. E. (2015). Awareness and acceptance of premarital genotype screening among youths in a Nigerian community. International Journal of Medical and Health $1(1)$, 17-21.

Retrieved fromhttp://discover.saemobilus.org/scholarlyjournalsbing?utm_source=bing\&utm_campaign

Rakotoniana, J. S., Jean de Dieu, M. R., \&Barennes, H. (2014). Can churches play a role in combating the HIV/AIDS epidemic? A study of the attitudes of Christian religious leaders in Madagascar. PloS one, 9(5), 97-131. https://doi.org/10.1371/journal.pone.0097131

Rivera-Hernandez, M. (2015). The role of religious leaders in health promotion for older Mexicans $\quad$ with diabetes. Journal of religion and health, 54(1), 303-315. doi: 10.1007/s10943-014 9829-Z

Ruijs, W. L., Hautvast, J. L., Kerrar, S., Van der Velden, K., \&Hulscher, M. E. (2013). The role of religious leaders in promoting acceptance of vaccination within a minority group: A qualitative study. BMC Public Health, 13(1), 1-23. https://doi.org/10.1186/1471-2458-13 511

Rumun, A. J. (2014). Influence of religious beliefs on healthcare practice. Int J Educ Res, 2(4), 37-48.

Widmer, M., Betran, A. P., Merialdi, M., Requejo, J., \&Karpf, T. (2011). The role of faith-based organizations in maternal and newborn health care in Africa.InternationalJournal of Gynecology \& Obstetrics, 114(3), 218222. 